GPJI 4(1)(2020)

\title{
BASKETBAL AS AN ALTERNATIVE METHOD TO LEARN SOCIAL COMPETENCE
}

\section{Baskoro Nugroho Putro}

Sebelas Maret University

baskoro.np@staff.uns.ac.id

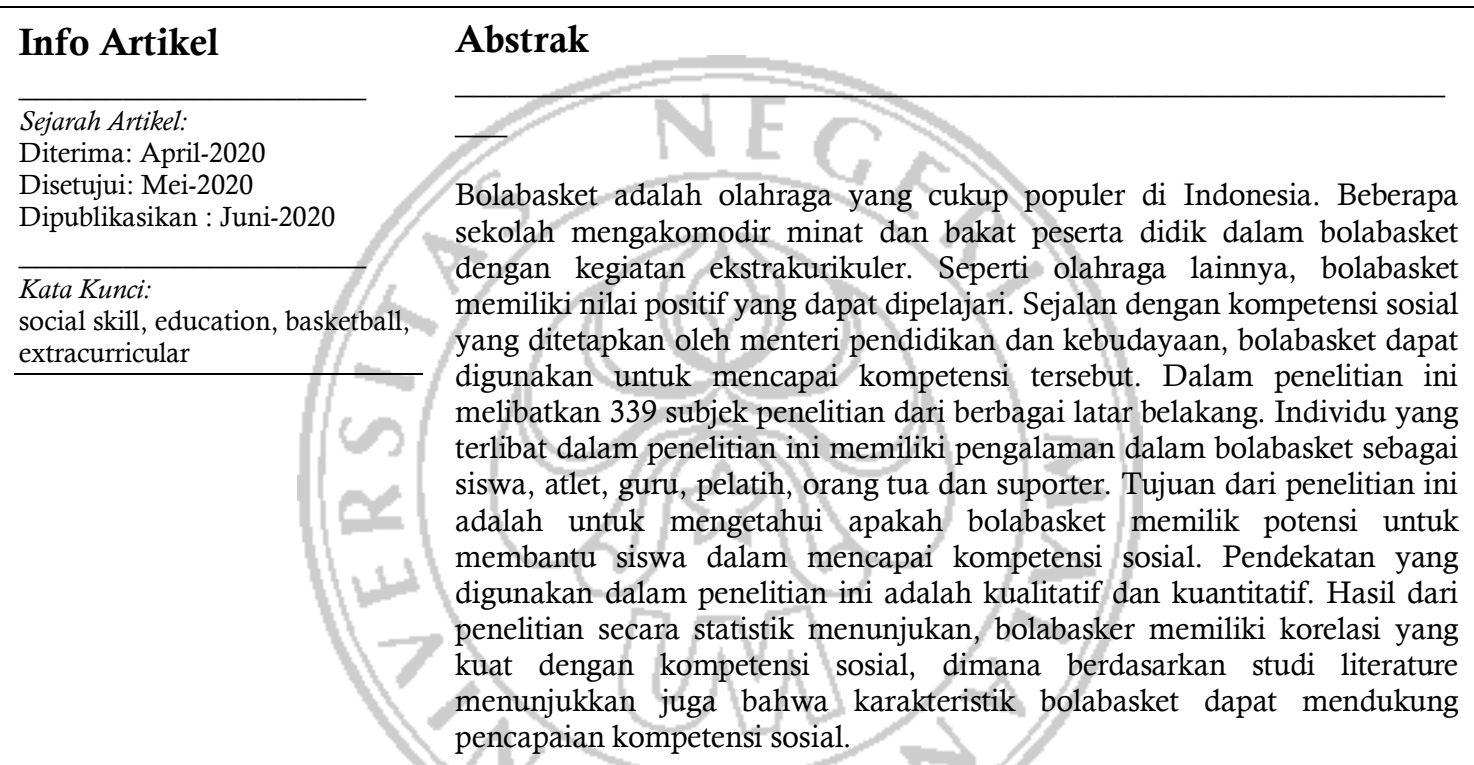

Abstract

Abstract

Basketball is a sport that is quite popular in Indonesia. Many schools accommodate the interests and talents of student at basketball in extracurricular activities. Like other sports, basketball has positive values that can be learned. In line with the social competencies established by the Ministry of Education and Culture, Basketball can be used to help achieve these competencies. This study involved 339 individuals from various backgrounds. Individuals that involved in research have experience in basketball as students, athletes, teachers, coaches, parent athletes, and supporters. The purpose of this study is to find out whether basketball has the potential to help students achieve social competence. The approach used in this research is qualitative and quantitative. The results of the research show that statistically, basketball has a strong correlation with social competence, whereas from theoretical studies the characteristics of basketball can support the achievement of social competence.

C 2020 Universitas Negeri Malang

Alamat korespondensi:

ISSN: 2614-8293 (Online)

E-mail: baskoro.np@staff.uns.ac.id 


\section{INTRODUCTION}

Sports have not always been managed to specifically prioritize health, evidence of the contribution of sport to health has not been consistent to date (Edwards \& Rowe, 2019). Apart from sports health, it can also be used as a means to educate. Education is not always about academic aspect, it can be a social aspect that can lead student to improve their skill to adapt with their life environment. There is a general opinion that social and moral values have an essential role in sports among children and adolescents (Elosua-oliden, 2017). Social competence is an important aspect that must be possessed by an individual. Matters relating to social skills should be learned to start early and as routinely as possible. Social skills can help people to live their daily lives well. Schools, as one of the providers of education, also facilitate students with learning related to social competence. Education is a conscious and planned effort to develop students' abilities to become fully educated human beings both cognitive, affective, and psychomotor (Menteri Pendidikan dan Kebudayaan, 2003; Ramdhani, 2014; Sudarsana, 2017). The primary and secondary education system in Indonesia sets four competencies that must be achieved. The core competencies are spiritual, social, knowledge and skills (Menteri Pendidikan dan Kebudayaan, 2016).

Generally, schools, as providers of formal education, provide facilities for students who have interests and talents in certain fields. Students who have interests and talents, both in sports and nonsports, are directed to participate in appropriate extracurricular activities. Extracurricular activities are one means of developing the potential, talents, interests, abilities, personalities, cooperation, and independence of learners optimally to support the achievement of national education goals (Hardianus, 2014; Menteri Pendidikan dan Kebudayaan, 2014).

Sport is not only a physical activity but also as a means of forming the characters who participate in it (Maksum, 2005). The sport element is found in physical education subjects. Involvement in sports and physical education has a positive impact because it is loaded with character values that can be used to form humans fully (Manik, 2016; Whitehead, Telfer, \& Lambert, 2013; Winarni, 2011). Basketball, which is a physical education material, has positive values that can be learned.

Basketball is one of the most popular sport and activities used (Svensson, Andersson, Mahoney, $\& \mathrm{Ha}, 2019)$. Basketball, as a sport, in schools is based on the positive development of young people which leads to gender equality, the formation of peaceful attitudes, the ease of socializing, and the development of young people themselves (Kang \& Svensson, 2019; Olushola, Jones, Dixon, \& Green, 2013). Values contained in basketball are communication, confidence, hard work and discipline, leadership responsibility, cooperation, honesty in playing, respecting friends and opponents, accepting defeat with grace, congratulating the winner, being fair play in play (Aditia, 2015; Carey, Showalter, Kelller, \& Neff, 2010)). Based on the competencies that must be achieved by students and the expected role in extracurricular activities in national education, basketball as one of the extracurricular activities has the potential to be able to help achieve competence in the field of social attitudes.

\section{METHOD}

Since this research accommodate both of numeric and narrative form of data, the approach used in research is quantitative and qualitative. The use of both approaches uses a sequential explanatory design (Maksum, 2018; Sugiyono, 2017). The data obtained were analyzed statistically and strengthened by the study of the literature.

The results of the two approaches will be thoroughly analyzed. A total of 363 individuals gave responses to the questionnaire and only responses from 339 individuals were used in the study. Not all data provided by respondents can be further analyzed because the data provided is not complete or does not answer all the questions in the questionnaire. The questionnaire is distributed through electronic media randomly. 


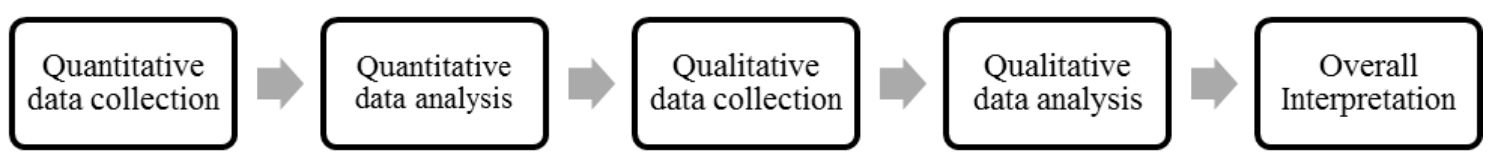

Figure 1. Sequential Explanatory Design Plot

\section{Quantitative data analysis}

At this stage, the data were analyzed statistically using SPSS version 25 . This data analysis use to check the validity and reliability of the questionnaire, furthermore the correlation between basketball experience and the social aspect also checked with SPSS.

The validity and reliability of the questionnaire were analyzed using Pearson Correlation and Cronbach's Alpha. As for the normality test using the Kolmogorov Smirnov test. In connection with the results of the normality test which shows that the data do not have a normal distribution, the correlation test uses non-parametric statistics, the Spearman method.

\section{Qualitative data analysis}

Correlation test results that show the relationship between basketball games with social skills competencies are strengthened with theoretical studies. The theoretical study is taken from the literature, official rules of basketball, additional regulations by the competition organizers, and research journals that lead to character building. This data analysis provide narrative description that support the result of correlation analysis.

\section{FINDINGS AND DISCUSSION}

A total of 339 respondents gave complete answers in this study. The age distribution of respondents showed as many as $n=7(2.1 \%)$ aged $<13$ years, $n=44(13 \%)$ aged $13-15$ years, $n=61$ $(18 \%)$ aged $16-18$ years, $n=54(15,9 \%)$ aged $19-22$ years, and $n=173(51 \%)$ aged $>22$ years. In the case of basketball-related experience, it was shown that as many as $n=2(0.6 \%)$ had $<1$ year experience, $n=64(18.9 \%)$ had $1-3$ years experience, and $n=273(80.5 \%)$ had experience $>3$ years. Basketball experience in this study is not only limited as an active player, but also athletes parents, teacher and supporters.

The results of testing the validity and reliability of the questionnaire showed that the questionnaire used was valid and reliable. The validity of the questionnaire was measured using Pearson Correlation, while the reliability of the questionnaire was measured using Cronbach's Alpha. The Pearson Correlation test results show that the $r$ count is greater than the $r$ table $(0.106)$, while the Cronbach's Alpha test results indicate that 8 question items have values $>0.60$.

Table 1. Questionnaire's Validity and Reliability

\begin{tabular}{ccc}
\hline Items & $\begin{array}{c}\text { Validity } \\
\text { (Pearson Correlation) }\end{array}$ & $\begin{array}{c}\text { Reliability } \\
\text { (Cronbach's Alpha) }\end{array}$ \\
\hline Basketball Experience &, 893 &, 920 \\
\hline Honesty &, 664 &, 928 \\
\hline Discipline &, 699 &, 926 \\
\hline Politeness &, 788 &, 923 \\
\hline Confidence &, 711 &, 926 \\
\hline Concern &, 789 &, 923 \\
\hline Collaboration &, 675 &, 927 \\
\hline Responsibility &, 783 &, 924 \\
\hline
\end{tabular}

Data normality test results using the Kolmogorov Smirnov test indicate the data do not have a normal distribution. The Kolmogorov Smirnov test results indicate all items $<0.05$. Then the correlation test uses non-parametric statistical methods. This step should be taken because of the condition and rule of statistical analysis. 
Table 2. Normality Test

\begin{tabular}{ccc}
\hline Items & $\begin{array}{c}\text { Validity } \\
\text { (Pearson Correlation) }\end{array}$ & $\begin{array}{c}\text { Reliability } \\
\text { (Cronbach's Alpha) }\end{array}$ \\
\hline Basketball Experience &, 893 &, 920 \\
\hline Honesty &, 664 &, 928 \\
\hline Discipline &, 699 &, 926 \\
\hline Politeness &, 788 &, 923 \\
\hline Confidence &, 711 &, 926 \\
\hline Concern &, 789 &, 923 \\
\hline Collaboration &, 675 &, 927 \\
\hline Responsibility &, 783 &, 924 \\
\hline
\end{tabular}

Based on statistical analysis Spearman correlation shows that there is a positive correlation between basketball experience with social competence and skills. It means that basketball experience can growth the social competence for the student that involved in basketball. The complete results of statistical analysis can be seen in Table 3 . The table will show how far the correlation of basketball experience.

Table 3 Correlation Test

\begin{tabular}{l|lrc}
\hline \multicolumn{2}{c}{ Correlation Between: } & $\begin{array}{c}\text { Spearman's Correlation } \\
\text { Result }\end{array}$ & Category \\
\hline & Honesty & 0,502 & \\
\cline { 2 - 4 } & Discipline & 0,582 & Moderate \\
\cline { 2 - 4 } Basketball Experience & Politeness & 0,649 & Strong \\
\cline { 2 - 4 } & Confidence & 0,629 & Strong \\
\cline { 2 - 4 } & Concern & 0,627 & Strong \\
\cline { 2 - 4 } & Collaboration & 0,646 & Strong \\
\cline { 2 - 4 } & Responsibility & 0,746 & Strong \\
\hline & & & Strong \\
\hline
\end{tabular}

The theoretical results of the study on basketball are there are a number of things that help students to achieve social attitudes and skills competencies. Here are some of the things contained in basketball results from theoretical studies (Barth \& Boesing, 2009; Carey et al., 2010; DBL, 2019; FIBA, 2018; McGee \& American Sport Education Program, 2007) namely, basketball are a team sport and fast game, special preparation is needed, regular scheduled practice, complete game rules, additional rules from organizer that give positive impact, players need to understand a lot of offense defense patterns and creatively combine the basic technique to make scores, almost all activities during the game are limited by time and communication, when practicing and competing, is also very important to coordinate.

Past research showed sports, including basketball, is an activity that can be used to conduct moral education because students involved in it can practice directly (Maksum, 2009; Surahni, 2017). The characteristics of basketball obtained from the results of theoretical studies show that basketball can be used as a means to assist students in achieving social attitude competencies. Those characteristics can be a perfect scenario for establishing interpersonal relationships and learning values, which, as consolidate, are reflected in social behaviors such as solidarity, cooperation and teamwork, positive influence of engagement with participation is derived from social experiences (Elosua-oliden, 2017). The following is a thorough research discussion:

Honest

Physical activity or sport has a better chance to increase honesty because participants are demanded to be honest in games (Wardana, Priambodo, \& Pramono, 2020). Every basketball competition, especially students, organizers always carry out a clarification process to prove that the players who will play are really concerned. The strict regulation and consistent implementation of the rules prevented the participants/teams who registered from the team from the fraud or manipulation of team members' data. The regulation directly accustoms the participants/teams to act honestly. 
Discipline

Environment is a factor that affect discipline, one of which includes the environment is a social environment (Arywibowo \& Priambodo, 2017). The environment in the club/extracurricular activities is an environment that is arranged so that the training process can run smoothly. A routine and timeconsuming training schedule accustoms students involved in discipline and to be able to manage time. It can be imagined if students are late to come to practice and do things that are not important after the exercise is finished. Arriving late results in reduced time for practice or lags behind a little or a lot of the material trained on that day. As students, trainees should return home immediately to prepare themselves for tomorrow's learning, rather than doing activities that are not useful. In addition to the problem of coming and going home during practice, discipline in hours of sleep must also be done so that the physical condition can be maintained properly. In the match, discipline is also taught through special rules governing the jersey of the match. The regulation states that in addition to the jersey itself, the color of the socks and accessories allowed to be used must be the same for one team. This can familiarize participants with extracurricular / club activities to be disciplined.

Polite

Sports, including basketball, can be used to educate the character of children where one of them is politeness (Yuliawan, 2016). Manners must be upheld by the participants of extracurricular/club activities both during training and competing. Participants in extracurricular/club activities must be polite when communicating with teammates and coaching staff during the exercise. When in a match against the matching device on duty also must be polite. Special rules are governing the players' behavior during a match, the rules are called technical fouls. A technical foul can be given to players if they do not respect the referee's decision, communicate rudely to the match, use language or show rude signals to the audience and try to provoke an opponent. The atmosphere of the training and the match that has been arranged can get the participants/club activities to be polite.

\section{Confidence}

Increased confidence can be obtained through involvement in practicing a sport (Wicaksono, 2009). Intense communication with practice partners who are from other classes or seniors in extracurricular activities and other schools at club practice can expand trainees' social networks. The number of friends you get will increase your confidence. Confidence can also be obtained when successfully entering the core team of a school or club and competing in a competition. Sports requires sports players to have confidence in being able to excel (Mirhan/\& Jusuf, 2016). Following the competition routinely will hone the confidence of participants in extracurricular / club activities.

\section{Care}

Involvement in sports shows that sport actors in it have a low anti-social nature and tend to have high social care (Rees, Howell, \& Miracle, 1990). Basketball is a sport that requires teamwork. Cooperation will not work well if it is not based on caring for teammates. Concern for teammates will foster good relationship chemistry between team members. Problems with the team can be resolved if there is concern among the members. Normally caring for team problems or teammates' problems will accustom the extracurricular / club participants to care about the environment.

To be responsible

Responsibility which is one of the positif value, can be obtained throuh play in sport or physical education (Utama, 2011). Each team member must be responsible for coming to practice regularly. Furthermore, during extracurricular exercises at schools or small clubs, participants are usually responsible for preparing and returning equipment used for training. At the time of the match, players must also be responsible for the goods that they bring themselves. The habit of being responsible both during training and competition will foster a sense of responsibility for extra-curricular / club activity participants. 


\section{CONCLUSION}

Achieving social competence through basketball is not impossible. Statistical studies show that there is a relationship between basketball experience and social competence. Theoretical discussion is strengthened that the basketball game has the potential to help achieve social competence. Physical education coaches or teachers must have character, not only able to teach but also able to instill positive values that can be learned from basketball (Hidayatullah, 2015).

The school does not only give support in providing basketball facility. Sports facilities influence on sport participation may, therefore, be varied and not necessarily have a positive impact on sport participation or its associated outcomes for users (Kumar, Elisavet, \& Hodgkinson, 2018). Without the role of a coach and physical education teacher the process of self-improvement cannot run optimally. A person who is able to provide, educate, direct, guide and evaluate during the process of planting positive values is needed for participants in extracurricular/club activities (Sulaiman, 2014; UU Republik Indonesia, 2005).

\section{REFERENCES}

Aditia, D. A. (2015). Survei Penerapan Nilai-Nilai Positif Olahraga Dalam Interaksi Sosial Antar Siswa Di SMA Negeri Se-Kabupaten Wonosobo Tahun 2014/2015. Journal of Physical Education , Sport, Health and Recreations, 4, 2251-2259.

Arywibowo, B. R., \& Priambodo, A. (2017). Hubungan Pola Asuh Orang Tua Terhadap Perilaku Disiplin Siswa dalam Pembelajaran Pendidikan Jasmani Olahraga dan Kesehatan (Studi pada Siswa Kelas XI-5 dân XI-9 SMA Negeri 7 Surabaya Tahun 2016/2017). Jurnal Pendidikan Olahraga Dan Kesehatan, 5(3), 401-405.

Carey, J., Showalter, D., Kelller, C., \& Neff, K. (2010). USA Basketball Youth Development Guidebook. Colorado: USA Basketball.

Edwards, M. B., \& Rowe, K. (2019). Managing sport for health : An introduction to the special issue. Sport Management Review, 22(1), 1-4. https://doi.org/10.1016/j.smr.2018.12.006

Elosua-oliden, P. (2017). The Values Associated with the Sport: Analysis and Evaluation of Sportspersonship. Revista de Psicodidáctica (English Ed.), 22(1), 29-36. https://doi.org/10.1387/RevPsicodidact.15918

Hardianus, D. (2014). Hubungan Kegiatan Ekstrakurikuler dengan Prestasi Belajar Siswa SMK Perindustrian Yogyakarta. State University of Yogyakarta.

Hidayatullah, M. F. (2015). Pendidikan Karakter: Tugas Mulia Pendidik. Solo: Cakra Wijaya.

Kang, S., \& Svensson, P. G. (2019). Shared leadership in sport for development and peace : A conceptual framework of antecedents and outcomes. Sport Management Review, 22(4), 464-476. https://doi.org/10.1016/j.smr.2018.06.010

Kumar, H., Elisavet, A., \& Hodgkinson, I. R. (2018). Sport participation : From policy , through facilities , to users ' health, well-being , and social capital. Sport Management Review, 21(5), 549562. https://doi.org/10.1016/j.smr.2018.01.002

Maksum, A. (2005). Olahraga Membentuk Karakter: Fakta atau Mitos? Jurnal Ordik, 3(1).

Maksum, A. (2009). Konstruksi Nilai Melalui Pendidikan Olahraga. Cakra, (1).

Maksum, A. (2018). Metode Penelitian dalam Olahraga (Kedua). Surabaya: UNESA University Press.

Manik, S. (2016). Etika dan Permasalahan dalam Pendidikan Jasmani dan Olahraga di Indonesia. Jurnal Ilmu Keolahragaan, 15, 71-88.

Menteri Pendidikan dan Kebudayaan. Undang-undang Sistem Pendidikan Nasional, Pub. L. No. 20 (2003). Indonesia: Re.

Menteri Pendidikan dan Kebudayaan. Peraturan Menteri Pendidikan dan Kebudayaan tentang 
Kegiatan EKstrakurikuler Pada Pendidikan Dasar dan Pendidikan Menengah, Pub. L. No. 62, 2 (2014). Menteri Pendidikan dan Kebudayaan.

Menteri Pendidikan dan Kebudayaan. Peraturan Menteri Pendidikan dan Kebudayaan tentang Standar Isi Pendidikan Dasar dan Menengah, Pub. L. No. 21, 177 (2016). Indonesia: Menteri Pendidikan dan Kebudayaan.

Mirhan, \& Jusuf, J. B. K. (2016). Hubungan antara Percaya Diri dan Kerja Keras dalam Olahraga dan Ketrampilan Hidup. Olahraga Prestasi, 12(1), 86-96.

Olushola, J. O., Jones, D. F., Dixon, M. A., \& Green, B. C. (2013). More than basketball: Determining the sport components that lead to long-term benefits for African-American girls. Sport Management Review, 16(2), 211-225. https://doi.org/10.1016/j.smr.2012.07.002

Ramdhani, M. A. (2014). Lingkungan Pendidikan dalam Implementasi Pendidikan Karakter. Jurnal Pendidikan Universitas Garut, 8(1), 28-37.

Rees, C. R., Howell, F. M., \& Miracle, A. W. (1990). Do High School Sports Build Character? A Quasi-Experiment on a National Sample, 27(3), 303-315.

Sudarsana, I. K. (2017). Membentuk Karakter Anak Sebagai Generasi Penerus Bangsa Melalui Pendidikan Anak Usia Dini. Purwadita, 1, 41-48.

Sugiyono. (2017). Metode Penelitian Kombinasi. Bandung: Alfabeta.

Sulaiman, I. (2014). Kompetensi Pelatih Ekstrakurikuler Bola Basket Tingkat SMP dalam Kejuaraan INLABS 2013. Sports Science Journal, 13, 60-65.

Surahni. (2017). Pendidikan Jasmani, Olahraga dan Kesehatan (PJOK) sebagai Sarana Pendidikan Moral. URECOL

Svensson, P. G., Andersson, F. O., Mahoney, T. Q., \& Ha, J. (2019). Antecedents and outcomes of social innovation: A global study of sport for development and peace organizations. Sport Management Review. https://doi.org/10.1016/j.smr.2019.08.001

Utama, A. M. B. (2011). Pembentukan Karakter Anak Melalui Kativitas Bermain dalam Pendidikan Jasmani. Jurnal Pendidikan Jasmani Indonesia, 8(1), 1-9.

UU Republik Indonesia. Undang-undang tentang Guru dan Dosen (2005). Indonesia: Presiden Republik Indonesia.

Wardana, A., Priambodo, A., \& Pramono, M. (2020). Pengaruh Model Pembelajaran Jigsaw dan Teams Games Tournament terhadap-Karakter Kepedulian Sosial dan Kejujuran dalam Pendidikan Jasmani Olahraga Kesehatan. Journal of Sport Scienece and Education, 5(3), 12-24.

Whitehead, J., Telfer, H., \& Lambert, J. (2013). Values in Youth Sport and Physical. New York: Routledge.

Wicaksono, D. (2009). Pengaruh Kepercayaan Diri, Motivasi Belajar Sebagai Akibat dari Latihan Bolavoli Terhadap Prestasi Belajar Atlet di Sekolah. Universitas Negeri Yogyakarta.

Winarni, S. (2011). Pengembangan Karakter dalam Olahraga dan Pendidikan Jasmani. Cakrawala Pendidikan, 124-139.

Yuliawan, D. (2016). Pembentukan Karakter Anak Dengan Jiwa Sportif Melalui Pendidikan Jasmani Olahraga dan Kesehatan. Sportif, 2(1), 101-112. 